\title{
EFFECTS OF DIFFERENT FACTORS ON THE GROWTH EFFICIENCY OF RICE SEEDLINGS
}

\author{
Munnujan Khanam* , Mohammad Al-Yeasa, Md. Sazzadur Rahman, \\ Abdullah-Al-Mahbub and A.R. Gomosta
}

Bangladesh Rice Research Institute, Joydebpur, Gazipur-1701, Bangladesh

Key words: Growth efficiency, Ageing, Rice, Salt solution, Seedling growth, Seed size

\begin{abstract}
Laboratory experiments were conducted to study the effect of salt solution, and size and ageing of seeds on growth efficiency of rice seedlings. Variation in growth efficiency due to different factors was significant. Seeds of Pokkali, BRRI dhan 29, BRRI dhan 40 and BRRI dhan 41 rice genotypes were used. Growth efficiency and other seedling characteristics decreased as salinity levels increased. Three varieties of rice BR 14, BRRI dhan 28 and BR 1, which are large, medium and small grain variety, respectively, were used to study the effect of seed size on growth efficiency and seedling growth. All the parameters decreased remarkably with decreasing seed size. Seed size influenced the growth efficiency significantly. For accelerated ageing test five varieties of freshly harvested seeds were used. The tested varieties responded differently for growth efficiency. When the ageing treatments were extended to 72 hours the growth efficiency depressed markedly for most of the varieties.
\end{abstract}

\section{Introduction}

At initial stage of seedling growth, growth of coleoptile and subsequent leaves is largely dependent on the seed reserve in the endosperm (Yoshida 1981). The growth efficiency (GE) indicates how much of the substrate is converted into the constituents of new tissues. It also evaluates the quantitative relationship between photosynthesis, respiration and growth (Tanaka and Yamaguchi 1968, Yamaguchi 1978). Yamaguchi and Tanaka (1995) observed that growth efficiency is almost constant during the actively growing stage, about $60-65 \%$, but it decreases with the advancement of growth and becomes very insifnificant at the end of plant growth. Yoshida (1981) stated that temperature changes the rate of growth but not the efficiency.

Salinity causes reduction in seedling growth. Increasing level of salinity cause loss in dry weight of seedling as well as reduction in length of root and shoot (Dubey and Rani 1989). Observations revealed that small seed sizes of groundnut produced significantly shorter seedlings than those produced from large seeds (Hossain et al. 2001).

Roberts (1981) found that severe damage to seed during ageing leads to reduced vigor and the production of abnormal seedlings.

A number of laboratory experiments were carried out to observe whether the growth efficiency remains constant or not if different factors are imposed on rice seed. Considering the factors: salinity, size of the seeds and accelerated ageing of seeds, three consecutive laboratory experiments were undertaken to observe (i) the effect of different salinity levels on growth efficiency, (ii) the effect of seed size on seedling growth, and (iii) the effects of accelerated ageing on growth efficiency of rice.

\section{Materials and Methods}

The research was carried out at the Plant Physiology division of Bangladesh Rice Research Institute (BRRI), Gazipur, Bangladesh during April to June, 2002.

\footnotetext{
*Corresponding author. E-mail: munnujan@dhaka.net
} 
Effect of salinity on growth efficiency: Four rice (Oryza sativa L.) varieties namely Pokkali, BRRI dhan 29, BRRI dhan 40, BRRI dhan 41 were used for determination of growth efficiency. Four concentration of salt solution viz. 5, 10, 15 and $20 \mathrm{dS} / \mathrm{m}$ were obtained by dissolving appropriate amount of $\mathrm{NaCl}$ culture solution (Yoshida et al. 1976). Twenty sprouted seeds of each variety were put in a $100 \mathrm{ml}$ beaker on a filter paper bed. The filter paper was moistened with different saline solutions separately. Four levels of saline solution and a non-saline solution (control) were used to grow seedlings. Twenty seedlings were allowed to grow in dark for 12 days at $30^{\circ} \mathrm{C}$ in an incubator. One $\mathrm{ml}$ of appropriate treatment solution was added to each beaker every day. After 12 days 10 seedlings were randomly selected from each beaker and seedling length was measured. Samples of only the seedlings were dried in a hot air circulating oven at $70^{\circ} \mathrm{C}$ for 72 hours. Dry weight was measured by using a fine electronic balance. One thousand seeds of each variety were weighed out in the electronic balance and mean weight of single seed was used as initial seed weight. Translocated reserve food and growth efficiency was calculated as per Yoshida (1981). The experiment was conducted in Complete Randomized Design with three replications.

Effect of Seed Size on Growth Efficiency of Rice: Three rice varieties BR 1, BRRI dhan 28 and BR 14 were used as small, medium and large grain to observe the effect of seed size on growth efficiency. Oven dried one thousand seed weight of BR 1, BRRI dhan 28 and BR 14 were 18.86, 19.03 and $26.59 \mathrm{~g}$ respectively. Sprouted seeds were grown in dark in an incubator for twelve days. The seedlings were grown with distilled water. Growth efficiency and amount of translocated reserve material were calculated as per Yoshida (1981).

Effect of accelerated ageing on growth efficiency of rice: Freshly collected seeds grown in Boro season (December, 2001 to May, 2002) of five rice varieties namely BR 1, BR 14, BRRI dhan 28, BRRI dhan 29 and BRRI dhan 36 were sun dried to break the dormancy. The sun-dried seeds were tested for germination. One thousand oven-dried seeds of each variety were weighed and mean weight of a single seed was used as initial seed weight.

Ageing technique: The ageing temperature and relative humidity were maintained at $43^{\circ} \mathrm{C}$ and $100 \%$, respectively, in an incubator. Seeds were aged at different durations of 24, 48 and 72 hours. After ageing, seeds were sun dried, Leaving $12 \pm 0.5$ per cent moisture content as determined by "KETT" moisture meter.

Twenty sprouted seeds of each variety were placed on a filter paper bed in each beaker. Freshly harvested and sun dried seeds (at 12 to 12.5 moisture \%) of each variety was used as control treatment. This experiment was also carried out following the procedure mentioned earlier. Collected data of each experiment were subjected to ANOVA test and the mean values were separated using DMRT (Gomez and Gomez 1976).

\section{Results and Discussion}

The results obtained from the three experiments are presented and discussed under separate heading in this chapter.

\section{A) Effect of salinity}

Growth efficiency: Salt solution affected the growth efficiency of all rice varieties (Table 1). In Pokkali, there was no significant variation in growth efficiency among the different salt concentrations with seedlings treated. A steep linear reduction in growth efficiency was evident as the salt concentration increased (Figs. 1a,b). Linear reduction in growth efficiency for BRRI dhan 29 was evident as the salt concentration increased with a slope value $b=-0.60$ (Fig. 1a). Many investigators indicate that rice is sensitive to salinity, particularly during the seedling stage (Maas and Hoffman 1977).

Seedling characteristics: Like growth efficiency seedling dry weight varied greatly across the $\mathrm{NaCl}$ concentrations in all the varieties (Table 2). Dry weight, as percentage of control, at 10 and 
$20 \mathrm{dS} / \mathrm{m}$ were respectively $96 \%$ and $76 \%$ for Pokkali, $92 \%$ and $59 \%$ for BRRI dhan $29,93 \%$ and $59 \%$ for BRRI dhan 40, 93 and $48 \%$ for BRRI dhan 41 . The results are in agreement with those of Amin et al. (1996) who observed that the higher the salt concentration the greater was the extent of reduction in shoot mass.

Table 1. Effect of different levels of salinity on growth efficiency of four different rice varieties.

\begin{tabular}{lcccc}
\hline Treatment & \multicolumn{4}{c}{ Growth efficiency $(\%)$} \\
\cline { 2 - 5 } EC $(\mathrm{dS} / \mathrm{m})$ & Pokkali & BRRI dhan 29 & BRRI dhan 40 & BRRI dhan 41 \\
\hline Control & $64.74 \mathrm{a}$ & $60.76 \mathrm{a}$ & $60.15 \mathrm{ab}$ & $64.42 \mathrm{a}$ \\
5 & $61.67 \mathrm{~b}$ & $59.41 \mathrm{ab}$ & $61.63 \mathrm{a}$ & $63.57 \mathrm{~b}$ \\
10 & $61.21 \mathrm{~b}$ & $57.96 \mathrm{~b}$ & $57.17 \mathrm{bc}$ & $63.46 \mathrm{bc}$ \\
15 & $60.65 \mathrm{~b}$ & $54.57 \mathrm{c}$ & $56.16 \mathrm{~cd}$ & $62.76 \mathrm{c}$ \\
20 & $59.95 \mathrm{~b}$ & $48.06 \mathrm{~d}$ & $53.66 \mathrm{~d}$ & $58.54 \mathrm{~d}$ \\
\hline
\end{tabular}

Means followed by a common alphabet in a vertical column are not significantly different at $5 \%$ level.
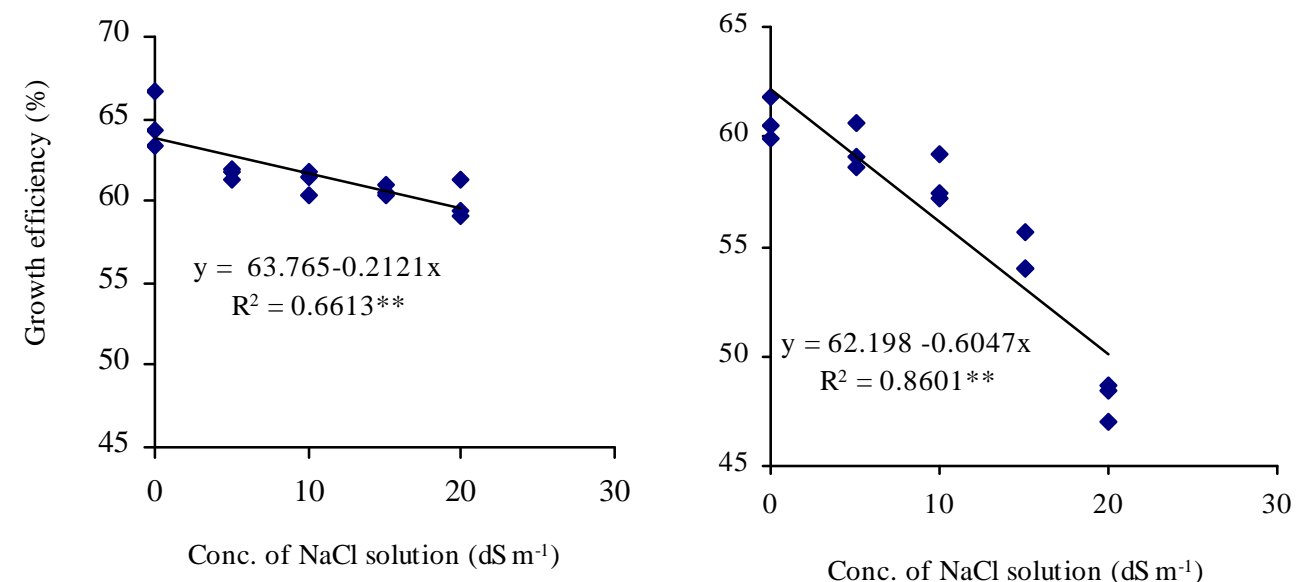

Fig. 1a. Relationship between the concentration of $\mathrm{NaCl}$ solution and the growth efficiency of pokkali and BRRI dhan 29.
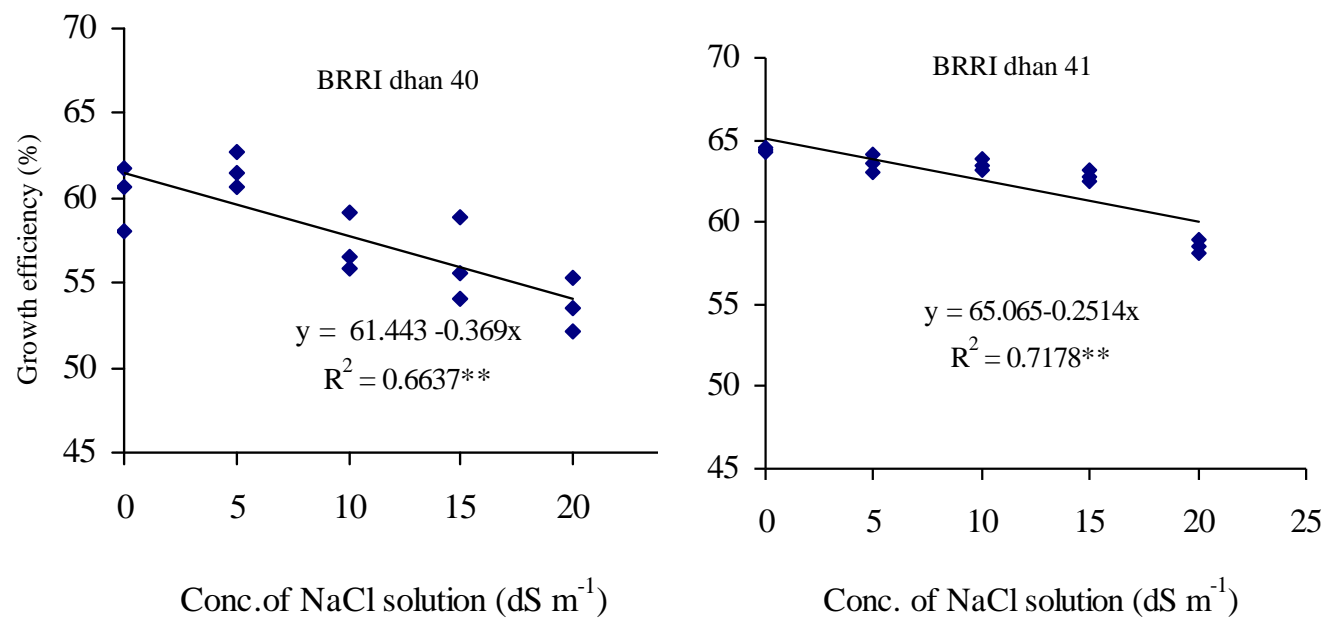

Fig. 1b. Relationship between the concentration of $\mathrm{NaCl}$ solution and the growth efficiency of BRRI dhan 40 and BRRI dhan 41 . 
The highest seedling length was observed in control treatment in all the varieties (Table 2). The mean shoot length decreased progressively with the increase of salinity level in all the varieties.

Table 2. Effect of different levels of salinity on seedling dry weight and length of four rice varieties.

\begin{tabular}{|c|c|c|c|c|c|c|c|c|}
\hline \multirow{2}{*}{$\begin{array}{l}\text { Treatment } \\
\text { EC } \\
(\mathrm{dS} / \mathrm{m})\end{array}$} & \multicolumn{4}{|c|}{ Seedling dry weight (mg/seedling) } & \multicolumn{4}{|c|}{ Seedling length $(\mathrm{cm})$} \\
\hline & Pokkali & $\begin{array}{c}\text { BRRI } \\
\text { dhan } 29\end{array}$ & $\begin{array}{c}\text { BRRI } \\
\text { dhan } 40\end{array}$ & $\begin{array}{c}\text { BRRI } \\
\text { dhan } 41\end{array}$ & Pokkali & $\begin{array}{c}\text { BRRI } \\
\text { dhan } 29\end{array}$ & $\begin{array}{c}\text { BRRI } \\
\text { dhan } 40\end{array}$ & $\begin{array}{c}\text { BRRI } \\
\text { dhan } 41\end{array}$ \\
\hline Control & $13.7 \mathrm{a}$ & $8.5 \mathrm{a}$ & $10.0 \mathrm{a}$ & $10.7 \mathrm{a}$ & $24.38 \mathrm{a}$ & $12.06 \mathrm{a}$ & $13.21 \mathrm{a}$ & $21.53 \mathrm{a}$ \\
\hline 5 & $13.3 \mathrm{~b}$ & $8.2 \mathrm{~b}$ & $10.4 \mathrm{a}$ & $10.4 \mathrm{~b}$ & $23.11 \mathrm{~b}$ & $11.05 \mathrm{~b}$ & $13.00 \mathrm{a}$ & $20.48 \mathrm{~b}$ \\
\hline 10 & $13.1 \mathrm{~b}$ & $7.8 \mathrm{c}$ & $9.3 \mathrm{~b}$ & $9.9 \mathrm{c}$ & $21.60 \mathrm{c}$ & $10.40 \mathrm{c}$ & $9.52 \mathrm{~b}$ & $18.68 \mathrm{c}$ \\
\hline 15 & $11.6 \mathrm{c}$ & $5.7 \mathrm{~d}$ & $8.7 \mathrm{~b}$ & $8.9 \mathrm{~d}$ & $15.56 \mathrm{~d}$ & $6.07 \mathrm{~d}$ & $7.88 \mathrm{c}$ & $12.94 \mathrm{~d}$ \\
\hline 20 & $10.4 \mathrm{~d}$ & $5.0 \mathrm{e}$ & $5.9 \mathrm{c}$ & $5.1 \mathrm{e}$ & $12.56 \mathrm{e}$ & $5.55 \mathrm{e}$ & $5.23 \mathrm{~d}$ & $5.48 \mathrm{e}$ \\
\hline
\end{tabular}

Means followed by a common alphabet in a vertical column are not significantly different at $5 \%$ level.

The amount of translocated reserve food was significantly affected by different level of salinity in all the varieties (Table 3). With increase in the level of salinity from $5 \mathrm{dS} / \mathrm{m}$ onward the amount of reserve food translocation reduced for all the varieties except Pokkali and BRRI dhan 40. In Pokkali the reduction trend was observed from $15 \mathrm{dS} / \mathrm{m}$ salt concentration.

Table 3. Effect of different levels of salinity on amount of translocated reserve from the seed to the seedlings of four rice varieties.

\begin{tabular}{lcccc}
\hline Treatment & \multicolumn{4}{c}{ Amount of translocated reserve $(\mathrm{mg} / \mathrm{seed})$} \\
\cline { 2 - 5 } EC $(\mathrm{dS} / \mathrm{m})$ & Pokkali & BRRI dhan 29 & BRRI dhan 40 & BRRI dhan 41 \\
\hline Control & $21.1 \mathrm{a}$ & $13.9 \mathrm{a}$ & $16.7 \mathrm{a}$ & $16.6 \mathrm{a}$ \\
5 & $21.6 \mathrm{a}$ & $13.8 \mathrm{a}$ & $16.8 \mathrm{a}$ & $16.4 \mathrm{a}$ \\
10 & $21.4 \mathrm{a}$ & $13.3 \mathrm{~b}$ & $16.2 \mathrm{ab}$ & $15.7 \mathrm{~b}$ \\
15 & $19.3 \mathrm{~b}$ & $10.5 \mathrm{c}$ & $15.5 \mathrm{~b}$ & $14.1 \mathrm{c}$ \\
20 & $17.3 \mathrm{c}$ & $10.3 \mathrm{c}$ & $10.9 \mathrm{c}$ & $8.7 \mathrm{~d}$ \\
\hline
\end{tabular}

Means followed by a common alphabet in a vertical column are not significantly different at $5 \%$ level.

\section{B) Effect of seed size}

Growth efficiency: The growth efficiency was highest (60.61\%) in larger seed-weight variety (BR14), while the lowest (55.59\%) was found in BR1 (Table 4), and thus the growth efficiency varied due to the amount of stored material present in the seeds.

Table 4. Effect of seed size on growth efficiency and other seedling characteristics of three rice varieties.

\begin{tabular}{lcccc}
\hline Varieties & $\begin{array}{c}\text { Growth } \\
\text { efficiency } \\
(\%)\end{array}$ & $\begin{array}{c}\text { Seedling } \\
\text { length } \\
(\mathrm{cm})\end{array}$ & $\begin{array}{c}\text { Seedling dry } \\
\text { weight } \\
(\mathrm{mg} / \text { seedling })\end{array}$ & $\begin{array}{c}\text { Translocated } \\
\text { reserve } \\
(\mathrm{mg} / \mathrm{seed})\end{array}$ \\
\hline $\begin{array}{l}\text { BR14 } \\
\text { (Large seed) }\end{array}$ & $60.61 \mathrm{a}$ & $15.23 \mathrm{a}$ & $12.0 \mathrm{a}$ & $19.8 \mathrm{a}$ \\
$\begin{array}{l}\text { BRRI dhan 28 } \\
\text { (Medium seed) }\end{array}$ & $58.03 \mathrm{~b}$ & $12.97 \mathrm{~b}$ & $8.1 \mathrm{~b}$ & $14.3 \mathrm{~b}$ \\
BR I (Small seed) & $55.59 \mathrm{c}$ & $11.30 \mathrm{c}$ & $8.0 \mathrm{~b}$ & $14.0 \mathrm{c}$ \\
\hline
\end{tabular}

Means followed by a common alphabet in a vertical column are not significantly different at $5 \%$ level. 
Seedling characteristics: Dry weight of seedling and seedling length of rice were significantly influenced by seed size. The highest seedling dry weight and seedling length was observed from large seed weight variety BR14 while, the lowest was observed in small seed weight variety BR1 (Table 4). The positive relationships between seed size and growth of seedling components (seedling dry weight and seedling length) observed in this study is similar to the reports on several forage legumes (Townsend and Wilson 1981). Similar result was also reported by Qiu et al. (1994) in common vetch.

\section{C) Effect of accelerated ageing}

Growth efficiency: As the ageing treatments were extended to $72 \mathrm{~h}$, the growth efficiency declined markedly in all the varieties (Table 5). The declination in growth efficiency at 72 hours ageing was due to physiological and biochemical factors associated with the adverse effect of accelerated ageing on germination and seedling growth were reported by other workers. Likhatchev et al. (1984) reported that depressed growth of soybean seedlings was a consequence of ageing of seed, which might have resulted from the decrease in soluble sugars and the hydrolysis of phytins.

Table 5. Effect of accelerated ageing on growth efficiency of five rice varieties.

\begin{tabular}{lccccc}
\hline \multirow{2}{*}{$\begin{array}{l}\text { Treatment } \\
\text { (ageing hours) }\end{array}$} & \multicolumn{5}{c}{ Growth efficiency (\%) } \\
\cline { 2 - 5 } & BR1 & BR14 & BRRI dhan28 & BRRI dhan29 & BRRI dhan36 \\
\hline Control & $56.26 \mathrm{a}$ & $60.01 \mathrm{a}$ & $58.44 \mathrm{~b}$ & $63.45 \mathrm{~b}$ & $61.91 \mathrm{a}$ \\
$24 \mathrm{~h}$ & $54.12 \mathrm{~b}$ & $57.74 \mathrm{a}$ & $64.76 \mathrm{a}$ & $68.16 \mathrm{a}$ & $61.01 \mathrm{a}$ \\
$48 \mathrm{~h}$ & $56.54 \mathrm{a}$ & $59.75 \mathrm{a}$ & $64.18 \mathrm{a}$ & $62.60 \mathrm{~b}$ & $60.97 \mathrm{a}$ \\
$72 \mathrm{~h}$ & $51.74 \mathrm{c}$ & $53.27 \mathrm{~b}$ & $54.47 \mathrm{c}$ & $62.31 \mathrm{~b}$ & $56.92 \mathrm{~b}$ \\
\hline
\end{tabular}

Means followed by a common alphabet in a vertical column are not significantly different at $5 \%$ level.

Seedling characteristics: At 72 hours ageing treatment seedling dry weight and seedling length decreased considerably in all the varieties (Table 6). The findings of the present study are in agreement with the findings of Paul and Mukherjee (1972). They reported that low respiration rate resulting from ageing might affect the seedling length (Table 7). The amount of reserve food translocation was not consistent with ageing hours for the test varieties.

Table 6. Effect of accelerated ageing on dry weight and length of seedling five rice varieties.

\begin{tabular}{|c|c|c|c|c|c|c|c|c|c|c|}
\hline \multirow{2}{*}{$\begin{array}{l}\text { Treatment } \\
\text { (ageing } \\
\text { hours) }\end{array}$} & \multicolumn{5}{|c|}{ Seedling dry weight (mg/seedling) } & \multicolumn{5}{|c|}{ Seedling length $(\mathrm{cm})$} \\
\hline & BR 1 & BR 14 & $\begin{array}{c}\text { BRRI } \\
\text { dhan } 28\end{array}$ & $\begin{array}{c}\text { BRRI } \\
\text { dhan } 29\end{array}$ & $\begin{array}{c}\text { BRRI } \\
\text { dhan } 36\end{array}$ & BR 1 & BR 14 & $\begin{array}{c}\text { BRRI } \\
\text { dhan } 28\end{array}$ & $\begin{array}{c}\text { BRRI } \\
\text { dhan } 29\end{array}$ & $\begin{array}{c}\text { BRRI } \\
\text { dhan } 36\end{array}$ \\
\hline Control & $8.1 \mathrm{a}$ & $11.7 \mathrm{a}$ & $8.2 \mathrm{~b}$ & $9.2 \mathrm{a}$ & $9.6 \mathrm{a}$ & $11.68 \mathrm{a}$ & $14.01 \mathrm{~b}$ & $13.15 \mathrm{c}$ & $11.83 \mathrm{a}$ & $13.58 \mathrm{a}$ \\
\hline $24 \mathrm{~h}$ & $7.7 \mathrm{~b}$ & $11.1 \mathrm{~b}$ & $8.8 \mathrm{a}$ & $9.0 \mathrm{a}$ & $9.6 \mathrm{a}$ & $11.81 \mathrm{a}$ & $14.58 \mathrm{a}$ & $14.76 \mathrm{~b}$ & $11.64 \mathrm{a}$ & $13.54 \mathrm{a}$ \\
\hline $48 \mathrm{~h}$ & $8.0 \mathrm{a}$ & $11.3 \mathrm{ab}$ & $8.8 \mathrm{a}$ & $8.3 \mathrm{~b}$ & $9.6 \mathrm{a}$ & $11.89 \mathrm{a}$ & $15.04 \mathrm{a}$ & $15.81 \mathrm{a}$ & $11.54 \mathrm{a}$ & $12.88 \mathrm{~b}$ \\
\hline $72 \mathrm{~h}$ & $7.5 \mathrm{~b}$ & $10.4 \mathrm{c}$ & $7.6 \mathrm{c}$ & $8.2 \mathrm{~b}$ & $9.0 \mathrm{~b}$ & $10.82 \mathrm{~b}$ & $12.44 \mathrm{c}$ & $11.62 \mathrm{~d}$ & $10.92 \mathrm{~b}$ & $11.25 \mathrm{c}$ \\
\hline
\end{tabular}

Means followed by a common alphabet in a vertical column are not significantly different at 5\% level.

The results of the above three experiments are in conflict with those of Yoshida (1981) and Tanaka and Yamaguchi (1995) who stated that growth efficiency of seedling remains almost constant (60 to $65 \%$ ) during the active growth stage.

So, it can be concluded from the results obtained during the present investigation, that (i) growth efficiency of seedlings is not constant. It varied due to salinity, size of the seeds and ageing treatment, (ii) growth efficiency decreased gradually with increased concentration of $\mathrm{NaCl}$ 
solution, (iii) growth efficiency was highest in large seed weight variety and lowest in small seed weight variety. (iv) the growth efficiency declined markedly in all the varieties when the ageing treatments were extended to 72 hours.

Table 7. Effect of accelerated ageing on amount of translocated reserve food during seedling growth of five rice varieties.

\begin{tabular}{lccccc}
\hline \multirow{2}{*}{$\begin{array}{l}\text { Treatment } \\
\text { ageing hours) }\end{array}$} & \multicolumn{5}{c}{ Amount of translocated reserve food (mg/seed) } \\
\cline { 2 - 6 } & BR1 & BR 14 & BRRI dhan 28 & BRRI dhan 29 & BRRI dhan 36 \\
\hline Control & $14.30 \mathrm{~b}$ & $19.48 \mathrm{a}$ & $14.01 \mathrm{a}$ & $14.54 \mathrm{a}$ & $15.54 \mathrm{a}$ \\
24 hours & $14.31 \mathrm{~b}$ & $19.11 \mathrm{~b}$ & $13.59 \mathrm{~b}$ & $13.11 \mathrm{~b}$ & $15.72 \mathrm{a}$ \\
48 hours & $14.12 \mathrm{~b}$ & $18.99 \mathrm{~b}$ & $13.75 \mathrm{~b}$ & $13.25 \mathrm{~b}$ & $15.80 \mathrm{a}$ \\
72 hours & $14.52 \mathrm{a}$ & $19.44 \mathrm{a}$ & $14.12 \mathrm{a}$ & $13.14 \mathrm{~b}$ & $15.81 \mathrm{a}$ \\
\hline
\end{tabular}

Means followed by a common alphabet in a vertical column are not significantly different at $5 \%$ level.

\section{References}

Amin, M., A. Hamid, M.T. Islam and M.A. Karim. 1996. Root and shoot growth of rice cultivars in response to salinity. Bangladesh Agron. J. 6(1\&2): 41-46.

Dubey, R.S. and M. Rani. 1989. Influence of $\mathrm{NaCl}$ salinity on growth and metabolic status of protein and acids in rice seedlings. J. Agron. and Crop Sci. 162: 92-106.

Gomez, K.A. and A.A. Gomez. 1976, Statistical procedures for agricultural research with emphasis on rice, IRRI, Los Banos, Philippines. pp. 294

Hossain, M.A., M.M. Kamal and M.S.A. Khan. 2001. Influence of seed size on growth, yield and seed quality of groundnut. Bangladesh J. Agril. Res. 26(4): 589-599

Likhatchev, B.S., G.V. Zelensky, K.G. Yel and Z.N. Shevchenko. 1984. Modelling of seed ageing. Seed Sci. and Technol.12: 385-393.

Maas, E.V. and G.J. Hoffmann. 1977. Crop salt toleance - current assessment. J. Irrigation and Drainage Div., ASCE. 103: 115-134.

Paul, A.K. and S. Mukherjee. 1972. Change in respiration rate of rice seedlings as affected by storage and viability and its possible relation with catalase and peroxidase activities during germination. Biol. Plantarum 14 (6): 114-419.

Qiu. J.A., J.A. Mosjidis and J.C. Williams. 1994. Seedling growth as affected by seed weight in common vetch. Agronomy J. 86: 251-255.

Roberts, E.H. 1981. Physiology of ageing and its application of drying and storage. Seed Sci. Tech. 9: 359372

Tanaka, A and J. Yamaguchi. 1968. The growth efficiency in relation to the growth of rice plants. Soil Sci. Plant. Nutr. 14: 110-116.

Townsend, C.E. and A.M. Wilson. 1981. Seedling growth of Cicer milkvetch as affected by seed weight and temperature regime. Crop Sci. 21: 405-409.

Yamaguchi, J. 1978. Respiration and the growth efficiency in relation to crop productivity. Res. Bull. Fac. Agri. Hokkaido Univ. 59: 59-129.

Yamaguchi, J. and A. Tanaka. 1995. Dynamic Aspects of Photosynthate Allocation, pp. 532-545. In: Science of the Rice Plant. Vol. II, Physiology. T. Matsuo, K. Kumazawa, P. Ishii, K. Ishihara and H. Hirata. Eds. FAPRC, Tokyo.

Yoshida, S., D.A. Forno and J.H. Cock. 1976. Laboratory Manual for Physiological Studies of Rice. IRRI, Los Banos, Phillipines. pp. 83.

Yoshida, S. 1981. Fundamentals of rice crop science. IRRI, Los Banos, Laguna, Philippines. pp. 269. 
